\title{
Levantamento preliminar de viroses de plantas cultivadas nos arredores de Manaus, Am (")
}

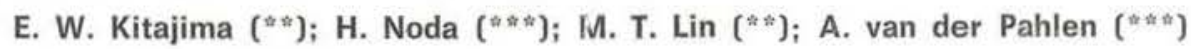

\begin{abstract}
Resumo
Um levantamento preliminar de viroses de plantas cultivadas nos arredores de Manaus foi feito em marco de 1977. Diversas propriedades particulares e campos experimentais foram inspecionados, anotando-se as plantas exibindo sintomatologia suspeita. A verificação da sua possível etiologia viral foi feita através de testes de transmissão, serologia e exames electronomicroscópicos. Foram constatadas diversas viroses em tomateiro, pimentão, quiabeiro, feijoeiro, cucurbitáceas, soja, feijão-de-asa, milho, etc. Como regra geral, ao contrário do que sucede no Sul do País, as viroses transmitidas por afídeos foram de ocorrência rara, presumivelmente porque as condiçōes climáticas da regiâo seriam desfavoráveis à biologia desses insetos
\end{abstract}

\section{INTRODUÇÃ̃o}

A bacia amazônica ocupa uma parte considerável do nosso território; gradativamente, a área cultivada em meio à hiléia amazônica está aumentando, até de maneira indiscriminada em certas regiōes.

Contudo, as informações sobre os problemas fitossanitários são escassos, tanto nas plantas nativas como nas cultivadas. Há necessidade imperiosa de se constatar quais as enfermidades atualmente existentes na vegetação autóctone e verificar sua patogenicidade sobre as plantas cultivadas, principalmente exóticas. Por outro lado, deve-se averiguar se as introduções feitas não estariam levando consigo patógenos, quer através de sementes, quer das partes vegetativas. Tais patógenos, em um nicho ecológico novo podem eventualmente ter efeitos devastadores.

Alguns desses problemas já têm sido abordados pelos pesquisadores do CPATU/EMBRAPA, CEPLAC e INPA. Contudo, para as viroses, literalmente inexistem informações, exceto o esclarecimento de um surto do vírus do

(*) - Pesquisa financiada pelo CNPq.

(*) - Universidade de Brasília, 70910 Brasilia, DF.

(**) - Instituto Nacional de Pesquisas da Amazônia, Manaus: mosáico do pepino, afetando a primenta-do-reino (Piper nigrum L.), em Tomé-Açu, PA (Costa et al., 1970). Numa rápida passagem por Manaus, um dos autores havia notado a ocorrência do vírus da faixa clorótica das nervuras do milho (Zea mays L.) (Kitajima \& Van Der Pahlen, 1977) e o vírus do mosáico da abóbora em maxixe (Cucumis anguria L.) (Lin et al., 1977).

Essa situação foi discutida com o Dr. W. E. Kerr, então Diretor do INPA, que imediatamente sugeriu um levantamento de viroses na região de Manaus, como ponto de partida, tendo oferecido toda a infra-estrutura de sua insti. tuição para tal. Esta comunicação relata o re. sultado desse levantamento preliminar, leva. do a cabo em meados de março de 1977.

\section{MATERIAL E MÉTOdos}

ÁREAS INSPECIONADAS - (1) Estação Experimental do INPA, Km 14; (2) Estação Experimental do INPA - Colégio Agrícola; (3) Colégio Adventista; (4) Propriedade do Sr. Tomoda. Cacau-Pirera; (5) Estação Experimental UEPAE/ EMBRAPA, Caldeirão; (6) Propriedade do Sr. Fausto, $\mathrm{Km}$ 62, estrada Manaus-Manacapuru; (7) Colônia Japonesa, $\mathrm{Km} \mathrm{40,} \mathrm{estrada} \mathrm{do} \mathrm{Alei-}$ xo; (8) Cachoeirinha; (9) ilha do Careiro.

Nas propriedades visitadas procurou-se verificar a ocorrência de plantas com sintomatologia de virose, avaliando-se também sua incidência. Amostras foram colhidas dessas plantas, para ulterior processamento em condições de laboratório, a fim de se tentar a detecçāo e identificação dos possíveis vírus nelas presentes.

TESTES DE TRANSMISSÃo - As tentativas de transmissão foram feitas no Laboratório de $\mathrm{Fi}$ - 
Lopatologia da Universidade de Brasília, tanto por métodos mecânicos como por enxertia. Os sintomas produzidos foram anotados e as plantas foram destruídas após a complementação dos testes.

MICROSCOPIA ELETRÔNICA - (a) Preparações "leaf dip" - todas as amostras colhidas foram examinadas em preparações "leaf dip" contrastadas negativamente (Kitajima, 1965) no próprio INPA, usando um microscópio eletrônico Zeiss EM 10; (b) Exames histológicos - algumas amostras foram fixadas em glutaraldeído, em tampão fosfato, em Manaus, e processadas posteriormente no Laboratório de Microscopia Eletrônica, na Universidade de Rrasilia, aonde as secções foram examinadas em um microscópio eletrônico JEOL JEM 100C.

SEROLOGIA - Testes serológicos, utilizando-se a coleção de anti-soros do Laboratório de Fitopatologia da Universidade de Brasília (Lin \& Kitajima, 1978), foram feitos por meio da técnica de dupla difusão em agar-gél.

\section{Resultados E DISCUSSÃo}

Os resultados desse presente levantamen. to acham-se expostos de maneira global na tabela 1. Nela acham-se incluídos além dos locais e das culturas inspecionadas, a sintoma. tologia observada e seu percentual de incidên. cia, bem como os dados dos testes de transmissão, exames ao microscópio eletrônico e reações serológicas.

Verificou-se de uma maneira geral que as viroses não ocorriam com alta freqüência, embora fossem constantes. As exceções säo representadas pelo vírus do mosáico da Vigna (VMV = Vigna Mosaic Virus) infetando o caupi (= feijāo-de-praia, feijăo macassar, feijāode-corda = Vigna unguiculata (L) Walp.), induzindo-lhe mosáico (Fig, 1A), chegando a inciciência a atingir valores da ordem de $80-100 \%$, com sérios prejuizos à produção. Também em cucurbitáceas - maxixe (Cucumis anguria) e abóbora (Cucurbita pepo L.) - o complexo virus do mosáico da abóbora (VMA $=$ Squash
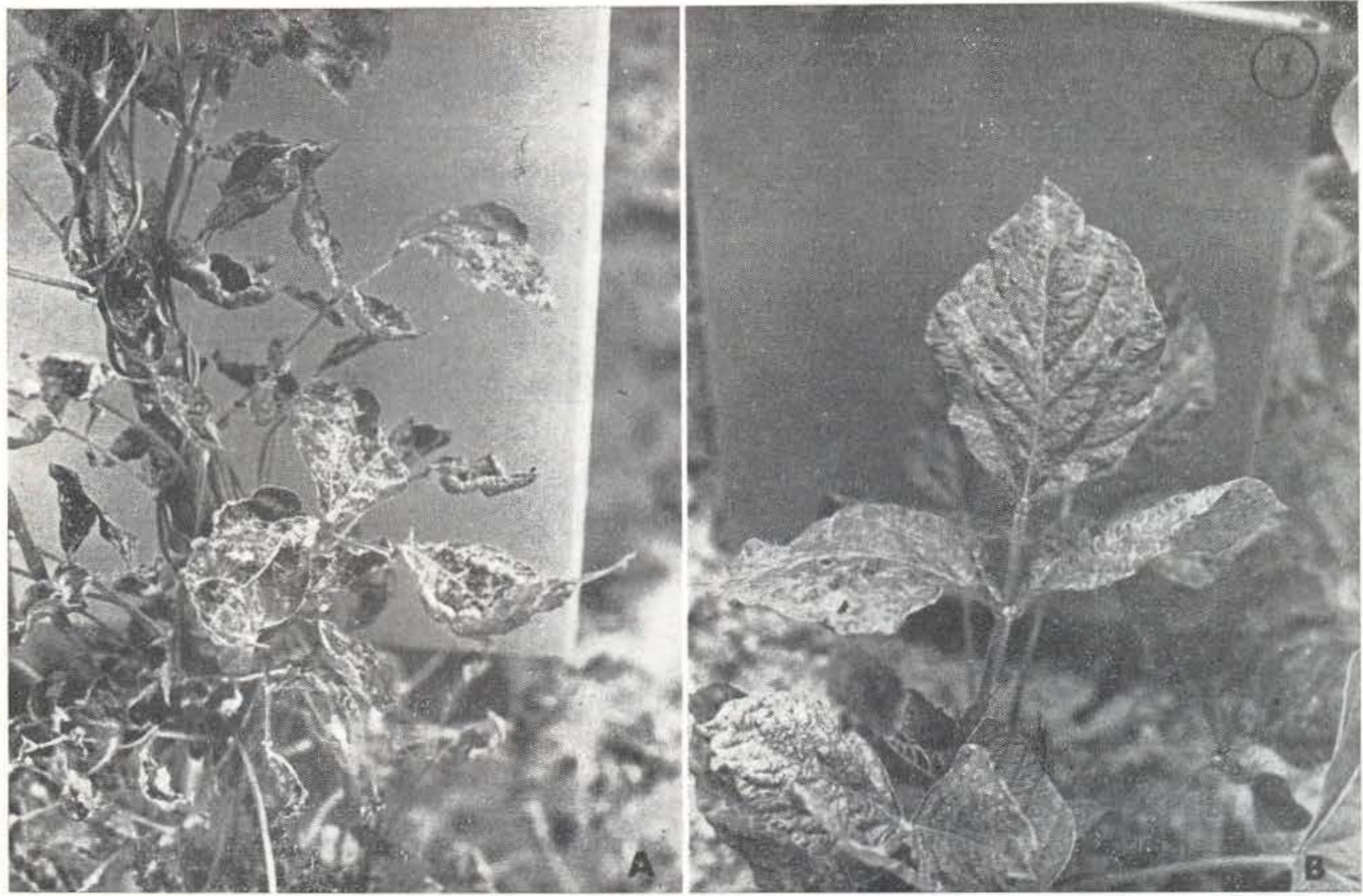

Fig. 1 - A - Planta de feijão-de-praia cơm sintomas de mosáico; B - Folha de soja, com sintomas de mosáico. 


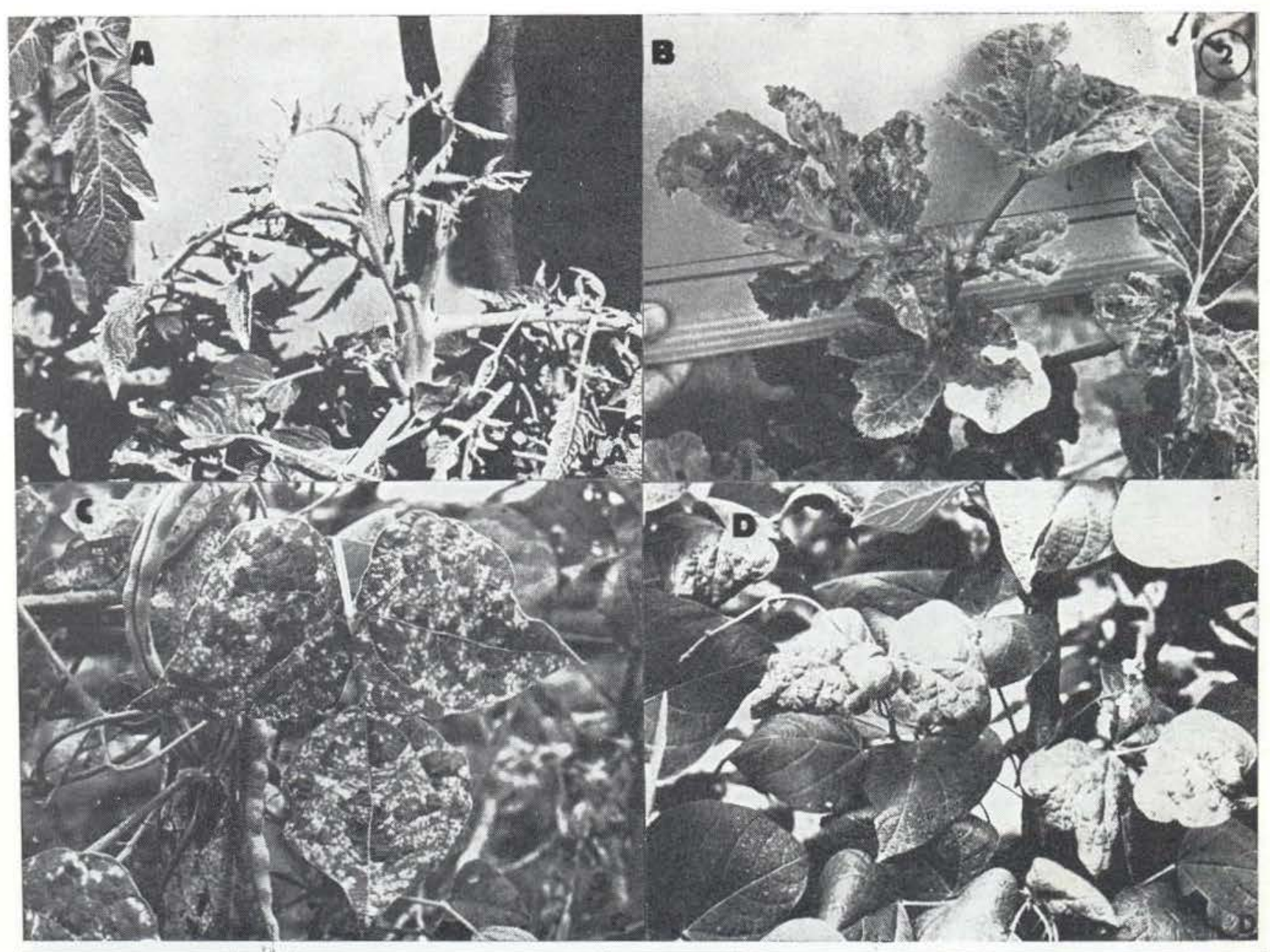

Fig. 2 - A - Parte apiçal de um tomateiro, com sintomas típicos de "curly top"; B - Quiabeiro, com sintomas de mosáico amarelo; C - Folha de feijoeiro, na Estação Experimental do INPA, exibindo um mosáica amarelo; D - Plantas de feijão-vagem, com mosáico e embolhamento nas folhas.

Mosaic Virus) e o mosáico da melancia (VMM $=$ Watermelon Mosaic Virus) - ocorria causando mosáico em $50 \%$ ou mais dessas plantas. Notou-se também a ocorrência freqüente de besouros crisomélidos nessas culturas. Esses vírus já foram relatados em outras partes do Brasil (Costa et al., 1969, 1972a; Caner et al., 1969; Lima \& Chagas, 1974; Cupertino et al., 1974 a, b; Siqueira et al., 1974; Lin et al., 1977; Costa et al., 1978; Batista et al., 1979). Nesses casos seria indicado investigar métodos de controle - técnicas culturais, controle do vector, uso de variedades resistentes, etc. - a fim de melhorar a produtividade. O VMV foi também identificado causando mosáico e⿳⺈ feijão-de-asa Psophocarpus tetragonolobus (L) DC), uma leguminosa introduzida pelo INPA e em estudos no INPA (Noda et al.,
1978). Detalhes dessa ocorrência serão relatados em outra publicação (Kitajima et al., 1979). O vírus de vira-cabeça (VVC) (Costa \& Forster, 1941) já conhecido em diversas regiōes do Brasil, e que é disseminado por trips, foi ocasionalmente encontrado em culturas de tomateiro (Lycopersicon esculentum Mill.) e pimentão (Capsicum annuum L.).

A identificação do VMV, VMA, VMM e VVC foi feita não só baseada na sintomatologia da planta infetada no campo, mas também pelos testes de transmissão, microscopia eletrônica Fig. 3A-C; Fig. 4A-D) e eventualmente, por serologia.

Um mosáico amarelo em tomateiro e uma malformação foliar de pimentão puderam ser transmitidas apenas por enxertia, não sendo 


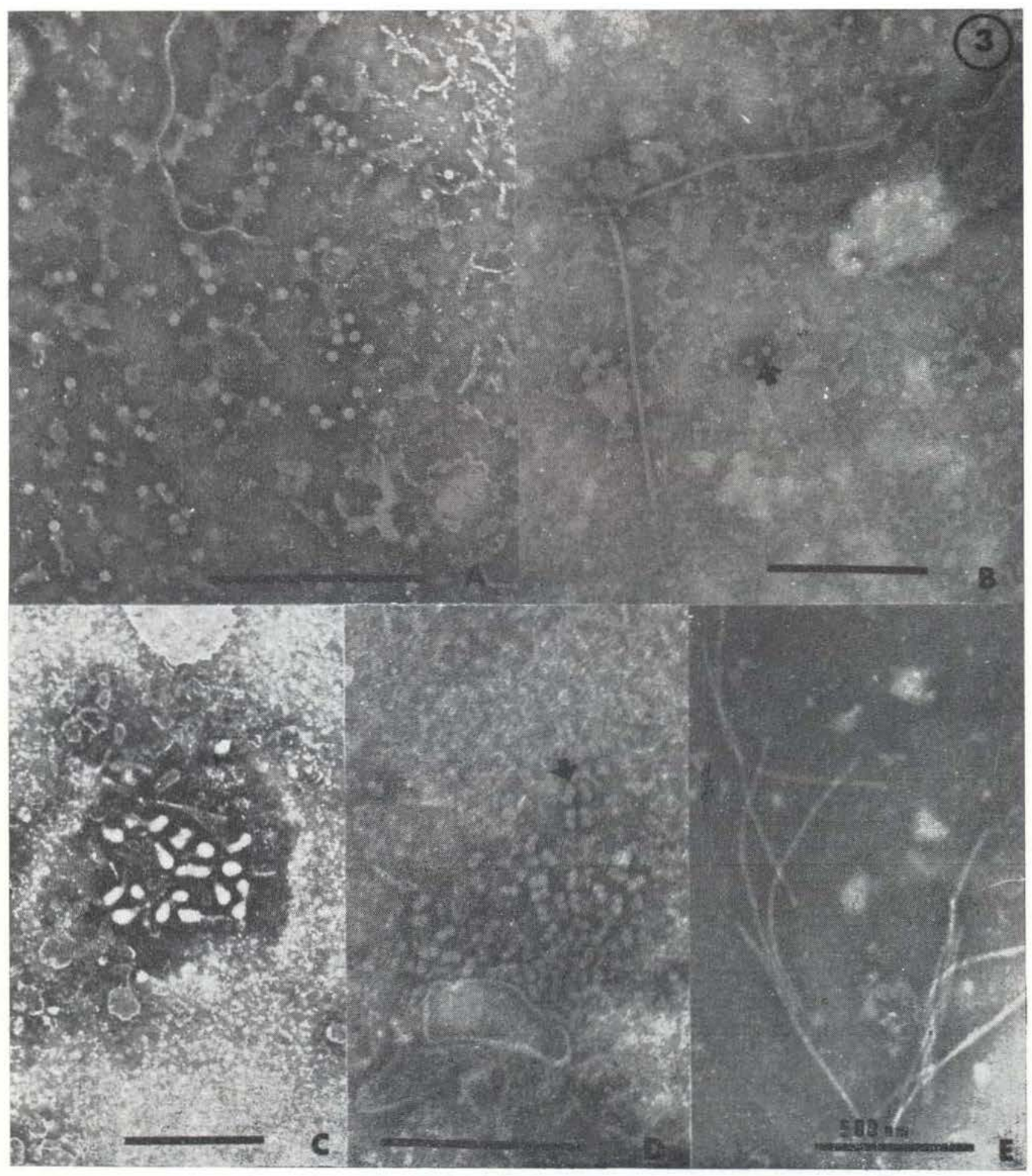

Fig. 3 - Preparaçōes "leaf dip" examinadas ao microscópio eletrônico, A - Partículas isométricas em folha de feijão-de-praia, com mosáico; B - Partícula alongaaa e flexivel, no vírus do mosáico da melancia, e isométrica (seta), do vírus do mosaico da abóbora, em folha de maxixe, com mosáico; C - grupo de partículas do vírus de vira-cabeça, em tomateiro exibindo necrose apical e manchas anulares nos frutos; D - Partículas geminadas (seta) em feijão-vagem com mosáico; E - Partículas alongadas em folha de cará, com mosqueado. Exceto na fig. 3D, as barras indicativas do aumento equivalem a $1 \mu \mathrm{m}$. 
possivel, contudo, detectar partículas suspeitas ao microscópio eletrônico. Possivelmente representam casos de infecção pelo vírus do mosáico dourado do tomateiro, transmitido por mosca branca (Costa, 1974) e do "curly top", que é disseminado por cigarrinhas (Costa, 1952). Tomateiros, com sintomas típicos de infecção pelo vírus do "curly top" foram ocasionalmente encontradas (Fig. 2A).

Plantas de feijoeiro, (Phaseolus vulgaris L.) com mosáico amarelo foram notadas esporadicamente na Estação Experimental do INPA, Km 14 (Fig. 2C), enquanto, na Colônia Japonesa, algumas plantas de feijão-vagem exibiam um mosáico (Fig. 2D). Essas condições não puderam ser transmitidas mecanicamente e os testes de enxertia não foram realizados, pois o material colhido não chegou em boas condições em Brasília, aliás, como sucedeu com uma boa parte das amostras. Num dos exames da amostra proveniente de feijăo-vagem. foram detectadas ao mícroscópio eletrônico, em preparações "leaf dip", partículas geminadas (Fig. 3D), similares às de alguns vírus transmitidos por mosca branca (Galvez \& Castaño, 1976; Matys et al., 1976 Goodman, 1977). Embora necessite mais estudos para confirmação, é possível que esta anomalia estivesse sendo causada por um vírus do grupo do mo. sáico dourado (Costa, 1965; Costa et al., 1972b).

Quanto ao mosáico amarelo, em quiabeiro (Hibiscus esculentus L.) (Fig. 2B), encontrado com certa freqüência, parece ser causado pelo vírus do grupo da clorose infecciosa das malváceas, de comum ocorrência em outras partes do país (Costa \& Carvalho, 1960), mas a hipótese requer confirmação através de estudos de transmissão mais elaborados, utilizando a mosca branca como vector.

De plantas de soja (Glycine max L.) (Fig. 1B) e feijão-de-porco (Canavalia ensitormes L.), com sintomas de mosáico não se obtiveram nenhuma informação que confirmasse sua etiologia viral e a questão continua em aberto. No caso de soja, o vírus do mosáico da soja parece estar excluído, pois é transmitido mecanicămente, e sendo um potyvirus (Bos, 1972), suas partículas seriam detectáveis em preparaçōes rápidas ao microscópio eletrônico e, em secções, as inclusões lamelares seriam observadas sem dificuldades.

O caso do cará (Dioscorea sp. L.) é interessante, pois embora partículas similares a potyvirus (Fig. 3E) tivessem sido encontradas em preparações "leaf dip", os exames de secções histológicas nada revelaram e os testes de transmissão foram negativos. A possibilidade de que tais partículas representem material normal não se acha totalmente excluída, muito embora já haja relatos de enfermidade de cará, causada por potyvirus (Hearon et al., 1978).

Um fato que chamou a atenção durante as inspeções realizadas foi a ausência quase total de afídeos na maioria das culturas visitadas, embora outros insetos vectores de alguns vírus, como cigarrinhas, trips, vaquinhas, além de ácaros, ocorressem em abundância. Os próprios lavradores mencionam que a infestação com pulgões não é freqüente, não obstante, em certas épocas, eles possam proliferar com rapidez e em quantidade. Este fenômeno acha-se provavelmente ligado ao fato de nesta região predominar elevada umidade relativa e temperatura ambiente, condições que não seriam favoráveis ao ciclo biológico dos pulgões. $E$, realmente, dentre os vírus encontrados, apenas o VMM é transmitido por afídeos.

Verifica-se assim que a disseminação e prevalência de viroses nessa região, pelo menos na época deste levantamento, têm um pad́rão distinto do que ocorre usualmente nos Estados do sul, centro-oeste e sudeste do País, onde as viroses transmitidas por pulgões são quase sempre predominantes. Se isto for confirmado, as medidas de controle dessas enfermidades podem ter um enfoque diferente.

Outros levantamentos estão sendo planejados, em épocas diferentes, não só na regiāo de Manaus, mas em outras localidades da bacia amazônica, para dar continuidade às pre. sentes constatações.

\section{AGRADECIMENTOS}

O autor principal agradece ao Dr Warwick E. Kerr, diretor do INPA, que possibilitou sua viagem a Manaus. 


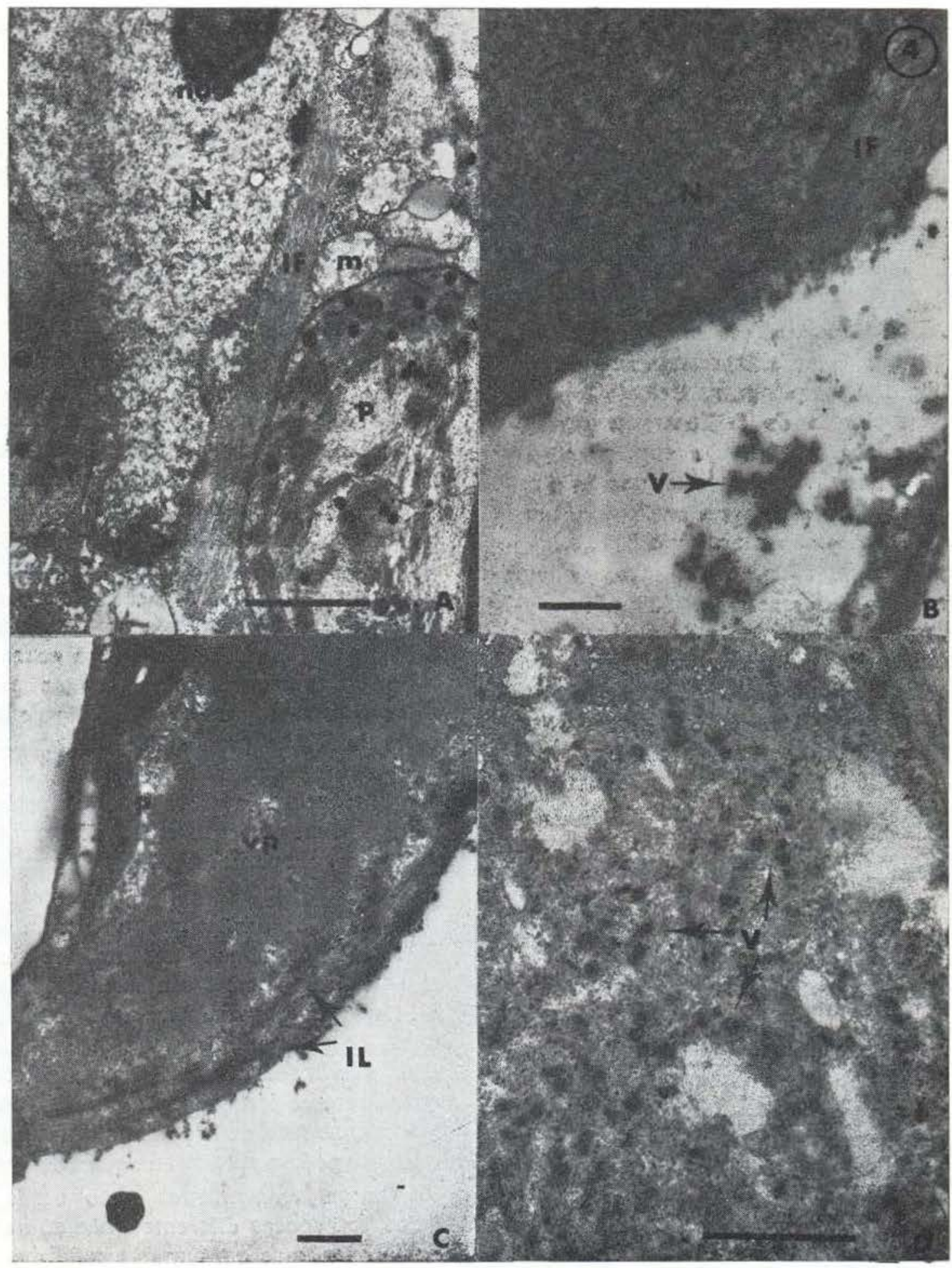

Fig. 4 - Micrografias eletrônicas de secçōes ultrafinas de tecido foliar de plantas com sintomas de viroses: A - Inclusão fibrosa (IF) no citoplasma de feijão-de-praia infetado pelo vírus do mosáico da Vigna; B — Partículas viraıs (V) no vacúolo e inclusões fibrosas (IF) no citoplasma adjacente ao núcleo (N) em feijăo-de-praia infetada pelo VMV; C - Parte do citoplasma de folha de maxixe, com mosáico, mostrando inclusões lamelares (IL) e viroplasma (vp) associadas à infecçāo pelo vírus do mosáico da melancia; D - Partículas de vírus (V) no retículo endoplasmático de tomateiro, infetado pelo virus de vira-cabeça. As barras nas micrografias equivalem a $1 \mu \mathrm{m}$. 


\section{SUMMARY}

A preliminary survey of viruses from cultivated plants in the Manaus region was made in March, 1977. Several private properties, besides experimental fields were inspected. After observation of field symptoms. samples from plants. suspected to be virus-infected, were taken, and experiments were made to identify the causal virus, by transmission tests, electron microscopy and serology. Several virus diseases were thus found in tomato, pepper, okra, cucurbitacea crops, bean, soybean, winged bean, etc. As a general rule, aphidborne virus diseases were rare, probably because the climatic conditions of the region are unfavorabie to the biology of aphids.

\section{BIBLIOGRAFIA}

Batista, Maria de Fátima; Costa, C.L.; Lin, M.T. \& KITAJTMA, E.W.

1979 - Identificação de Diabrotica bivittula (Kir.). um crisomelideo, como vector do vírus do mosáico da abóbora. Fitopatologia Brasileira, 4: 92.

Bos, L.

1972 - Soybean mosaic virus. CMI/AAB Description of plant viruses n. 93

Caner, J.; Silberschmidt, K. \& Flores, Elza

1969 - Ocorrência do vírus do mosáico da Vigna no Estado de São Paulo. O Biológico, 35: 13-16.

Costa, A.S.

1952 - Further studies on tomato curly top in Brazil. Phytopathology, 42: 391-403.

1965 - Three whitefly-transmitted virus diseases of beans in Săo Paulo, Brazil. FAO Plant Protection Bull., 13: 1-12.

1974 - Moléstias de tomateiro no Brasil transmitidas pela mosca branca Bemisia tabaci. Fitopatologia, Lima, 9: 47.

Costa, A.S. \& Carvalho, ana Maria B.

1960 - Mechanical transmission and properties of the Abutilon mosaic virus. Phytopath Zeit., 37: 259-272.

COSTA, A.S, \& Forster, R.

1941 - Identidade do vírus de vira-cabeça e sua inclusăo no grupo do "spotted wilt". Bragantia, 1: 491-516.

Costap A.S.; Albuquerque, F.C.; IKeda, H. \& Cardoso, M.

1970 - Moléstia da pimenta-do-reino causada pelo vírus do mosáico do pepino. MA - EPE
Inst. Pesq. Exp. Agropec. Norte (IPEAN) - Série Fitotecnia 1 (1).

Costa, A.S.; Kitajima, E.W. \& Nagat, H.

1972a - Alguns virus que afetam o pepino no Estado de São Paulo. In: Res. 12: Reun. An. Soc. Oleric. Brasil, Fortaleza.

Costa, A.S.; Kitajima, E.W.; Miyasaka, S. \& ALMeIDA, L.D

1972b-Moléstias causadas por virus. In: Anais do I Simpósio Brasileiro do Feijão. Univ. Fed. Viçosa.

Costa, A.S.; Oliveira, A.R.; Kitajima, E.W. \& MatsUoKA, S.

1969 - Ocorrência do mosáico do feijẫo macassar em Săo Paulo. Rev. Soc. Bras. Fitopat., 3: $56-57$

Costa, A.S.; Lin, M.T.; Kitajima, E.W.; SANtos, A.A.; Mesquits, R.C.M. \& FreIrE Fo, F.R.

1978 - Cerotoma arcuata (Oliv.), um crisomélido vector do mosáico da Vigna no Brasil. Fitopatologia Brasileira, 3: 81-82.

Cupertino, F.P.: Costa, C.L.: Kitajima, E.W.; Mattos, J.K.A. \& Araujo, M.T.

1974a - Viroses de cucurbitáceas no Distrito Federal. Fitopatologia, Lima, 9: 51.

1974b-Ocorrência do virus do mosáico da Vigna no Distrito Federal. Fitopatologia, Lima, 9: 51

Galvez, G.E. \& Castaño, M.

1976 - Purification of the whitefly-transmitted bean golden mosaic virus. Turrialba, 26: 205-207.

GoOdMAN, R.M.

1977 - Single-stranded DNA genome in a whitefly transmitted plant virus. Virology, 83: 171-179.

Hearon, S.S.; Corbett, M.K.; Lawson, R.H.; Gillaspie, A.G. JR. \& WATERWORTH, H.E.

1978 - Two flexouous-rod viruses in Dioscorea floribunda : symptoms, identification, and ultrastructure. Phytopathology, 68: 1137-1146.

KITAJIMA, E.W.

1965 - A rapid method to detect particles of some spherical plant viruses in fresh preparations. J. Electron Microscopy, Tokyo, 14: 119-121.

Kitajima, E.W.; \& Van Der Pahlen, A.

1977 - Ocorrência do vírus da faixa clorótica das nervuras do milho no Distrito Federal e em Amazonas. Fitopatologia Brasileira, 2: 83-84.

KrтAjima, E.W.; Noda, H.; Lin, M.T. \& Costa, C.L. 1979 - Um mosáico em feijâo-de-asa causado pelo virus do mosáico da Vigna. Fitopatolo. gia Brasileira (submetido à publicação). 
Lin, M.T. \& KiтAJima, E.W.

1978 - Preparo de anti-soros para a seroteca da Universidade de Brasília. Fitopatologia Bra. sileira, 3: 93-94.

Lima, J.A.A. \& Chagas, J.M.G.

1974 - Estudos preliminares de um vírus constatado em Vigna sinensis Endl. no Estado do Ceará. Fitopatologia, Lima, 9: 58.

Lin, M.T.; Ávilı, A.C.; KItAJima, E.W. \& VAN Der PAHLEN, A.

1977 - Identificação e ocorrência do vírus do mosáico da abóbora no Distrito Federal e no Estado do Amazonas. Fitopatologia Brasileira, 2: 86-87.
Matys, J.C.; Silva, D.M.; Oltveira, A.R. \& Costa, A.S.

1976 - Morfologia de três virus transmitidos por Bemisia tabaci. Fitopatologia, Lima, 11: 22.

Noda, H.; Junk, W. \& Van Der Pahlen, A.

1978 - Emprego de macrofitas aquáticas ("Matupá") como fonte de matéria orgânica na cultura de feijão-de-asa (Psophocarpus tetragonolobus) em Manaus. Acta Amazonica, 8: 107-110.

Siqueira, O.; Kuhn, G.B. \& Tourinho, M.C.P.

1974 - Mosáico da abóbora (Cucurbita sp.). Fitopatologia, Lima, 9: 72 .

(Aceito para publicação em 17/08/79). 
TABELA 1 - Plantas com sintomas de virose encontradas durante um levantamento feito em Manaus e arredores, em março de 1977, e os resultados dos testes de transmissão, exames electrono-microscópicos e reaçōes seroiógicas efetuadas para a identificação dos possíveis víras causadores.

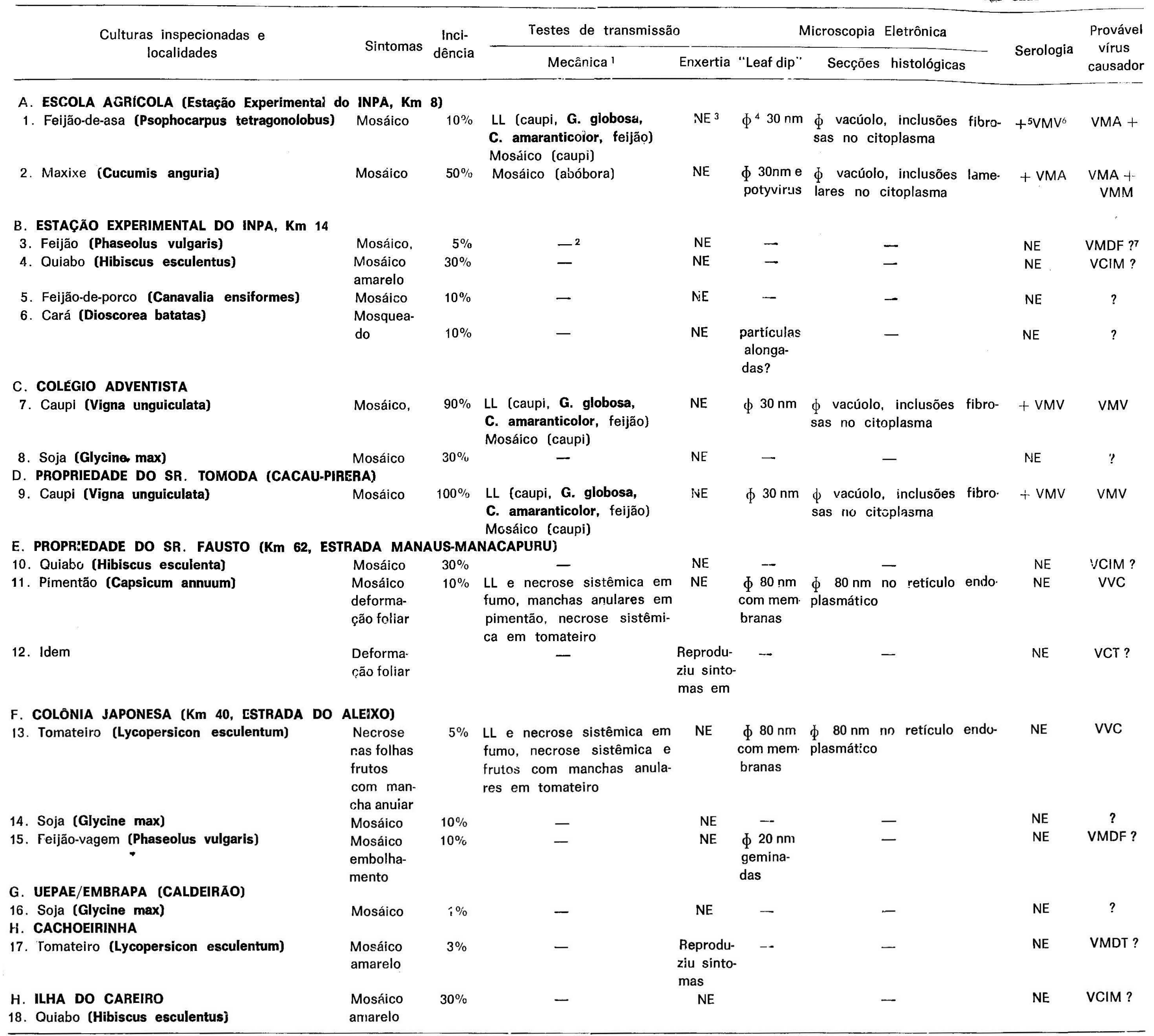

( 1) - Extração do suco em tampão fosfato $0,01 \mathrm{M}, \mathrm{pH} 7$, e sufito de sódio $0,1 \%$; inoculação mecânica com auxílio de carborundo 500 miesh. LL - lesões locais; ${ }^{(2)}-=$ resultados negativos; $\left({ }^{3}\right)-N E=$ não efetuado; $\left({ }^{4}\right)-\phi=$ partícula esferoidal, isométrica; $\left({ }^{5}\right)-+$ reação serológica positiva contra o anti-soro do vírus indicado; $\left.{ }^{6}\right]$ - VMV - vírus do mosáico da Vigna; VVC - virus de vira-cabeça; VMA - vírus do mosáico da abóbora: VMM - vírus do mosáico da melancia; VCIM - vírus da clorose infecciosa das malváceas; VMDF - vírus do mosáico dourado do feijoeiro; VMDT - vírus do mosáico dourado do toniateiro; VCT - vírus do "curly top"; $\left.{ }^{7}\right)$ - ? = identificação ainda não feita ou duvidosa. 